\title{
OBITUÁRIO: SABA MAHMOOD — UM TRABALHO PIONEIRO NA BATALHA DAS IDEIAS ${ }^{1}$
}

OBITUARY: SABA MAHMOOD — PIONEERING WORK IN THE BATTLE OF IDEAS

Judith Butler ${ }^{2}$

Nascida em Quetta, Paquistão, em 1962, Saba Mahmood imigrou para os Estados Unidos em 1981 para estudar arquitetura e planejamento urbano na Universidade de Washington, em Seattle. Ela recebeu seu Ph.D. em antropologia da Universidade de Stanford, em 1998, e ensinou na Universidade de Chicago antes de se transferir para a Universidade da Califórnia, Berkeley, em 2004, onde ofereceu seu último seminário em 2017.

Professora Mahmood fez contribuiçôes inovadoras para debates contemporâneos sobre o secularismo, propondo novos modos de se entender a religião na vida pública e contestando concepçôes dominantes sobre a religião e o secular.

Diante das vozes estridentes, que se apressavam a denunciar as sociedades muçulmanas no contexto pós 11 de setembro, ela trouxe uma compreensão mais nuançada e educada acerca do Islá para dentro de debates travados nos campos das teorias feministas, da ética e da política.

Suas publicaçôes e apresentaçóes reverberaram através das Humanidades e das Ciências Sociais, moldando de forma profunda uma nova geração de acadêmicos interessados em uma abordagem mais reflexiva e crítica acerca da religião na modernidade.

1 Tradução por Bruno Reinhardt.

2 Judith Butler é filosofa e teórica do gênero. Seu trabalho tem influenciado a filosofia política, a ética e a terceira onda do feminismo e da teoria literária. Desde 1993, ela ensina na Universidade da Califórnia, Berkeley, onde é professora no Departamento de Literatura Comparativa e no Departamento de Teoria Crítica. E-mail: jpbutler@berkeley.edu.

Debates do NER, Porto Alegre, Ano i9, N. 36, P. I43-I46, Ago./Dez. 20 i 9 
Como pesquisadora e professora, ela incorporava e era guiada por fortes princípios morais e políticos, oferecendo análises agudas sobre o poder colonial e capitalista através de sua abordagem para o secularismo, e formulou novos modos de se entender temas como o feminismo, a subjetividade relacional, a liberdade religiosa, a injúria, os direitos das minorias religiosas, e as legislaçôes seculares e religiosas sobre a família e a sexualidade.

Na companhia dos antropólogos Talal Asad e Charles Hirschkind, professora Mahmood mostrou que o secularismo é uma formação política complexa, que produz diferenças entre as tradiçóes religiosas que ele mesmo visa regular. Em suas palavras, "o secularismo político é o poder soberano do Estado moderno de reorganizar traços substantivos da vida religiosa, estipulando o que a religião é ou deve ser, pautando seu conteúdo próprio, e disseminando subjetividades, enquadramentos éticos e práticas cotidianas concomitantes" (Mahmood, 2016, p. 3).

O secularismo nunca escapa às sua próprias histórias religiosas, nem adquire autonomia com relação às formaçóes históricas que ele pretende regular. De fato, a distinção entre público e privado, central para a razão secular, funda-se sobre uma ênfase cristã moderna na devoção privada. Esse enquadramento religioso cristáo, focado na crença, contrasta fortemente com tradiçóes como o Islá, que enfatizam o papel das práticas corporais para a vida religiosa. Como resultado, ela argumenta, as epistemologias seculares não podem capturar como o Islã articula valores religiosos, interpretando erroneamente tanto o sujeito islâmico quanto os significados públicos de suas práticas.

No campo da teoria feminista, Mahmood desafiou suas leitoras a entender que as mulheres muçulmanas devotas que estudou no Cairo não eram sujeitos irrefletidamente obedientes, mas que de fato se engajavam de forma ativa com uma hermenêutica corânica específica, em escolas por elas geridas, cultivando práticas religiosas como formas de conduta ética.

Desafiando visóes sobre a liberdade subjetiva defendidas pela filosofia moral Ocidental, ela propóe um argumento corajoso e desafiador: para se entender a agência feminina no Islã devemos conceber um sujeito moldado 
por sua relação com as representações textuais e imagísticas do divino. As mulheres que abraçam práticas desse tipo, ela argumentou, estão se dedicando a um projeto de cultivo de si.

Em seu último livro, ela estudou a discriminação contra cristãos ortodoxos Coptas no regime secular do Egito contemporâneo. Contra a visão que afirma que as diferenças tribais e religiosas seriam evidência de um processo incompleto de secularização, ela mostrou como as diferenças e conflitos religiosos foram exacerbados por regimes seculares de poder. Longe de realizar ideais de igualdade cívica e política, o Estado secular facilitou desigualdades e violências religiosas.

Professora Mahmood foi autora de Religious Difference in a Secular Age: a Minority Report (Princeton University Press, 2015) e de Politics of Piety: the Islamic Revival and the Feminist Subject (Princeton University Press, 2005), que ganhou o prestigioso Victoria Schuck Award, da Associação Americana de Ciências Políticas ${ }^{3}$. Seu trabalho foi traduzido para o árabe, francês, persa, português, espanhol, turco e polonês. Professora Mahmood foi também recipiente de várias honrarias e prêmios, incluindo uma Axel Springer Fellowship, da Academia Americana em Berlim, e prêmios da Centre for Advanced Study in the Behavioural Sciences, da Universidade de Stanford, e do Humanities Research Institute, da Universidade da Califórnia.

Professora Mahmood foi uma pesquisadora brilhante, uma estimada colega, e uma professora e orientadora dedicada. Além de sua paixão política e análises refinadas, ela era grande apreciadora das belezas naturais, da poesia de Ghalib, do prazer de cozinhar e compartilhar excelente comida. Ela cultivava com enorme e alegre atenção suas relaçôes com parentes e amigos.

Ela treinou seus estudantes com cuidado e intensidade notáveis, demandando seu melhor trabalho, ouvindo, respondendo com enorme generosidade, pensando de forma viva e solicitando que os outros fizessem o mesmo. Em seus meses finais, ela reafirmava os valores do pensamento livre e do amor,

3 Nota dos editores: Religious Difference ganhou o 2016 Clifford Geertz Prize in the Anthropology of Religion, da Associação Americana de Antropologia.

Debates do NER, Porto Alegre, ANo i9, N. 36, P. I43-I46, Ago./Dez. 20 i 9 
tendo deixado para trás um vibrante legado que persistirá e florescerá entre todos aqueles cujas existências foram tocadas por sua vida e obra. Ela deixa seu marido, Charles Hirschkind, seu filho, Nameer Hirschkind, e seus irmãos Tariq Mahmood e Khalid Mahmood, que vivem e trabalham no Paquistão.

\section{REFERÊNCIAS}

MAHMOOD, Saba. Religious Difference in a Secular Age: a Minority Report. Princeton: Princeton University Press, 2016.

Recebido em: 28/10/2019

Aprovado em: 28/10/2019 